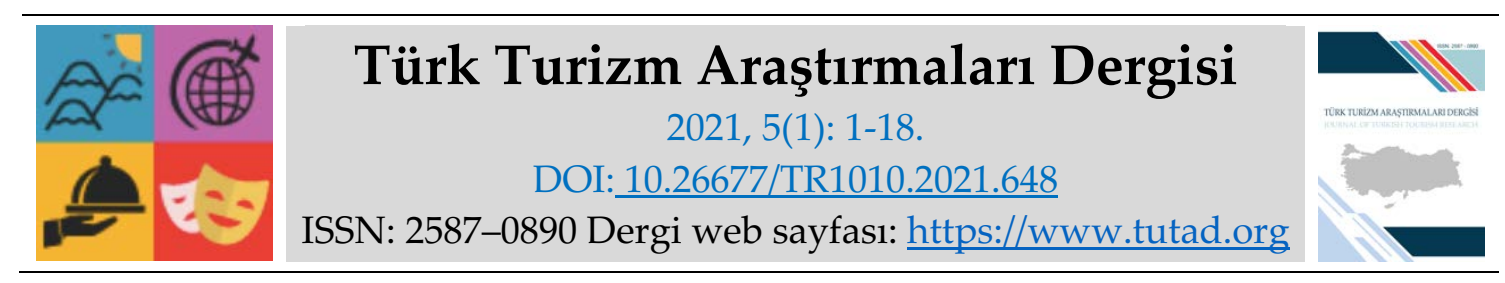

ARASTTIRMA MAKALESI

\title{
Turizmde Destinasyon Rekabetçiliği: Alanya ve Kemer Turizm Destinasyonları Arasında Karşılaştırmalı Bir Analiz*
}

Ahmet DUMAN, Yüksek Lisans Öğrencisi, Alanya Alaaddin Keykubat Üniversitesi, Sosyal Bilimler Enstitüsü, Antalya, e-posta: ahmetduman07@gmail.com

ORCID: https://orcid.org/0000-0002-7722-8340

Dr. Öğr. Üyesi Serpil KOCAMAN, Alanya Alaaddin Keykubat Üniversitesi, Turizm Fakültesi, Antalya, e-posta: serpil.kocaman@alanya.edu.tr

ORCID: https://orcid.org/0000-0002-2037-7441

Öz

Bu çalışmanın amacı Türkiye'nin güney kıyılarında yer alan, Antalya iline bağlı Alanya ve Kemer turizm destinasyonlarının rekabet faktörlerini belirlemek ve her iki destinasyonun rekabet güçlerini karşılaştırarak demografik değişkenlere göre farklılık gösterip göstermediğini tespit etmektir. Araştırma verileri Alanya ve Kemer turizm destinasyonlarında 2019 yaz sezonunda tatillerini yapan yabancı turistlere anket uygulanarak elde edilmiştir. Elde edilen bulgular doğrultusunda fiziksel çevre ve altyapı açısından Kemer'in, turistik olanaklar ve hizmet kalitesi açısından ise Alanya'nın daha rekabetçi olduğu görülmüştür. Doğal ve kültürel çekicilikler ile, turistik hizmetler açısından ise her iki destinasyon arasında bir farklılık görülmemiştir. Konukseverlik Alanya'nın en rekabetçi faktörü olurken, doğal çekim unsurlarının ise, Kemer'in en rekabetçi faktörü olduğu görülmüştür.

* Bu makale, Ahmet DUMAN'ın yüksek lisans tezinden üretilmiştir.

Anahtar Kelimeler: Destinasyon Rekabetçiliği, Turizm, Alanya, Kemer.

Makale Gönderme Tarihi: 09.11.2020

Makale Kabul Tarihi: 01.03.2021

\section{Önerilen Atıf:}

Duman, A. ve Kocaman, S (2021). Turizmde Destinasyon Rekabetçiliği: Alanya ve Kemer Turizm Destinasyonları Arasında Karşılaştırmalı Bir Analiz, Türk Turizm Araştırmaları Dergisi, 5(1): 1-18. (C) 2021 Türk Turizm Araştırmaları Dergisi. 


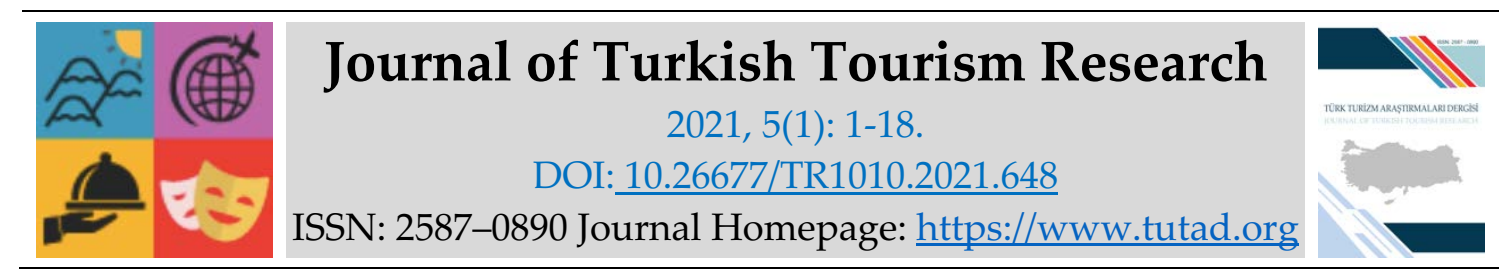

\title{
$\underline{\text { RESEARCH PAPER }}$
}

\section{Destination Competitiveness in Tourism: A Comparative Analysis Between Alanya and Kemer Tourism Destinations}

Ahmet DUMAN, MSc. Student, Alanya Alaaddin Keykubat University, Social Sciences Institute, Antalya, e-mail: ahmetduman07@gmail.com ORCID: https://orcid.org/0000-0002-7722-8340

Assistant Prof. Dr. Serpil KOCAMAN, Alanya Alaaddin Keykubat University, Faculty of Tourism, Antalya, e-mail: serpil.kocaman@alanya.edu.tr ORCID: https://orcid.org/0000-0002-2037-7441

\begin{abstract}
The aim of this study is determining the competitive factors and comparing competitiveness factors according to demographic variables of visitors in Alanya and Kemer which is located in Turkey's southern coast. The research data were obtained by applying a questionnaire to foreign tourists who made their holiday in 2019 summer season in Alanya and Kemer tourism destinations. According to the findings, it is seen that Kemer is more competitive in terms of physical environment and infrastructure and Alanya is more competitive in terms of touristic facilities and service quality. There is no difference between natural and cultural attractions and touristic services for both destinations. While hospitality is the most competitive factor of Alanya, it is seen that natural attraction is the most competitive factor of Kemer.
\end{abstract}

Keywords: Destination Competitiveness, Tourism, Alanya, Kemer.

Received: 09.11.2020

Accepted: 01.03.2021

\section{Suggested Citation:}

Duman, A. and Kocaman, S. (2021). Destination Competitiveness in Tourism: A Comparative Analysis Between Alanya and Kemer Tourism Destinations, Journal of Turkish Tourism Research, 5(1): 1-18.

(C) 2021 Türk Turizm Araştırmaları Dergisi. 


\section{Gíriş}

Birleşmiş Milletler Dünya Turizm Örgütü 2019 yılı verilerine bakıldığında, nispeten güçlü bir küresel ekonomi tarafından yönlendirilen uluslararası turistlerin sayısı, gelişmekte olan ekonomilerde büyüyen bir orta sınıf, teknolojik gelişmeler, yeni iş modelleri, uygun fiyatlı seyahat seçenekleri ve vize kolaylığı gibi faktörlerin etkisi ile 2018 'de $\% 5$ artışla 1,4 milyara ulaşmıştır. Bu rakama, Dünya Turizm Örgütü'nün öngördüğü tarihten iki yıl önce ulaşılması da turizm endüstrisi için önemli bir gelişme olarak değerlendirilmektedir. 23. Dünya Turizm Örgütü Genel Kurulu tarafından yayınlanan en son UNWTO Dünya Turizm Barometresi'ne göre, uluslararası turist sayısı Ocak - Haziran 2019 aralığında 2018 ilk altı aylık döneme göre \%4 artış göstermiştir. Turizmden elde edilen uluslararası gelir dikkate alındığında, 2018 yılında edilen turizm geliri UNWTO tarafından 1,7 trilyon dolar olarak açıklanmıştır. Bu sonuç sektörü diğer sektörler içerisinde ekonomik büyüme ve gelişme için gerçek bir küresel güç haline getirmekte, daha fazla ve daha iyi işlerin yapılmasını teşvik etmektedir. Turizm, özellikle gelişmekte olan ülkeler için katalizör görevi görerek toplumların kalkınması ve dönüşmesinde önemli bir rol almaktadır (UNWTO, 2019). Son yedi yıl boyunca aralıksız olarak turizm ihracatının birçok ülkedeki ticaret açığını azaltarak, mal ihracatından daha hızlı büyümesi, destinasyonlar arasında turizm ve seyahat alanındaki rekabet ortamını daha da kızıştırmıştır (Kocaman, 2020: 107).

Turizm ve seyahat endüstrisi; ulaşım, konaklama, gastronomi, rekreasyon ve eğlence gibi alt sektörleri ile ülke ekonomilerine sağladığı önemli döviz girdileri ve yarattığı istihdam firsatları nedeniyle dünyadaki en önemli endüstrilerden biridir (Demir ve Çevirgen, 2006: 58). Turizm ve seyahat endüstrisi, turizm terminolojisinde destinasyon olarak adlandırılan turist çeken bölgeler arasında da yoğun bir şekilde rekabete etki eden bir endüstridir. Bir destinasyonun ziyaretçileri açısından memnuniyet sağlayıp pazar payını arttırabilmesi destinasyonun rekabet gücünü etkileyen en önemli faktörlerden biridir. Bu nedenle destinasyonu yönetenler destinasyonların rekabette avantaj yaratan faktörlerini sürekli geliştirmeli ve destinasyonun rekabetçi konumunu doğru tanımlamalıdır (Omerzel, 2006: 167).

Günümüzde turizm destinasyonları, geçmişte olduğundan daha fazla rekabet halindedir. Özellikle 20.yüzyıldan itibaren toplumsal hayatta yaşanan ekonomik, sosyal ve teknolojik bazı değişimler küresel piyasadaki rekabeti keskinleştirmektedir. Diğer tüm sektörler gibi turizm sektörü de bu değişimden etkilenmektedir (Hassan ve Uşaklı, 2013: 54). Doğal, kültürel ve tarihi kaynaklar, altyapı, erişilebilirlik, ilgi çekici yerler ve tesisler destinasyonların rekabet faktörleri olan unsurlardır. Ziyaretçiler farklı destinasyonlara yönelik ziyaretleri sonucu elde ettikleri deneyimleri ve gözlemledikleri hizmet standartlarını karşılaştırırlar (Kozak ve Baloğlu, 2011: 9). Turizm hareketliliğinin yaşandığı destinasyonlar yaşanılan deneyim ve gözlemlerin fazlasıyla karşılaştırıldığı alanların en başındadır. Bu deneyim ve gözlemler çoğu zaman yakın çevreye tavsiye etme, destinasyona tekrar gelme gibi sonuçlar doğurduğu gibi, destinasyonun marka imajı ve marka kişiliğine oldukça etki eden unsurlar haline gelmektedir.

$\mathrm{Bu}$ araştırmanın amacı Alanya ve Kemer kıyı destinasyonları arasında destinasyon rekabet faktörlerini belirlemek ve her iki destinasyonun rekabet güçlerini analiz etmektir

\section{KAVRAMSAL ÇERÇEVE}

Bir destinasyonunun rekabet edebilirliğini tanımlamak, rekabet kavramının hem kapsamı ve karmaşıklığı hem de farklı boyutlar içeren çok yönlü doğası sebebi ile tartışma ve karışıklık içermektedir (Fernandez vd., 2020). Destinasyon rekabetçiliği, günümüzde turizm araştırmacıları arasında ilginin giderek yükseldiği bir çalışma alanı haline gelmiştir (Enright ve Newton, 2004). 
Turizm literatürü incelendiğinde, destinasyonlar arası rekabet gücü çalışmalarının ilk olarak 1990 'lı yıllarda çalışılmaya başlandığı görülmektedir. Destinasyonların rekabetçi yapılarını farklı yazarlar farklı bakış açıları ile ele almış ve farklı modeller geliştirmişlerdir. Destinasyon rekabetçiliğinin ölçümü ile ilgili hem birincil veriler ile yapılan çalışmalar hem de ikincil veriler ile yapılan çalışmalar bulunmaktadır (Hassan, 2000; Dwyer ve Kim, 2003; Dwyer, 2004; Enright ve Newton, 2004; Bahar ve Kozak, 2005; Kayar ve Kozak, 2007; Ritchie ve Crouch, 2010; Croes ve Kubickova, 2013; Zehrer ve Hallman, 2015; Sanchez ve Lopez 2015; Zehrer vd., 2016; Kubickova, 2017; Armenski vd., 2017; Goffi vd., 2018; Andrades ve Dimanche, 2019; Nazmfar vd., 2019).

Destinasyon rekabetçiliğini tanımlamak için farklı perspektifler kullanılmıştır (Goffi ve Cucculelli, 2018). Rekabet kavramı ile ilgili tarihsel süreç içerisinde en fazla ilgilenen kişilerden birisi olan ve "Mutlak Üstünlükler Teorisi" isimli yaklaşımı ile bilinen Adam Smith'e göre rekabetçilik, ekonomik bir aktivite olmakla birlikte ekonomik stratejilerin belirlenmesinde özgürlük olarak algılanmaktadır. Smith'e göre, eğer piyasa tam bir özgürlüğe sahipse, herhangi bir ürünün fiyatı üzerinde sürekli olarak doğal fiyatı seviyesinde kalmasına yönelik bir baskı sürekli olacaktır (Tokatlığlu, 1999: 7). Literatürde ise rekabetçilik konusundaki çalışmalar "Klasik İktisat Teorileri" ve "Modern İktisat Teorileri" kapsamında ele alınmıştır. "Merkantalizm" olarak adlandırılan ülkeler arası değerli madenlerin ele geçirilmesinin sağladığ avantaj klasik iktisat teorilerinin başlangıcı olarak kabul edilirken, Smith'in “Mutlak Üstünlükler Teorisi" konuya yeni bir bakış açısı getirmiştir. Torrens ve Ricardo'nun "Karşılaştırmalı Üstünlükler Teorisi" de, Smith'in teorisi üzerine yeni bakış açıları getirmiştir. "Faktör Donatımı Teorisi" ve "Leontief Paradoksu" diğer klasik iktisat teorileridir. "Nitelikli İş Gücü" teorisi, "Teknoloji Açı̆̆ 1 Teorisi", "Ürün Dönemleri Teorisi”, "Tercihlerde Benzerlik Teorisi” ve "Ölçek Ekonomisi Teorisi" ise modern iktisat teorileri kapsamında rekabetçilik araştırmalarının teorik altyapısını oluşturur.

1980'li yıllara gelindiğinde rekabet, hizmet sektörlerinde de artan oranda yaygınlaşmıştır. Firmalar, dünya çapında satışlar yapmayı, dünya çapında ürün tedarik etmeyi ve düşük maliyetli faktörlerden faydalanmayı bir rekabet stratejisi olarak geliştirmiştir (Porter, 1990: 14). Porter (1990) başarı kriterlerini incelediği ülke endüstrilerinin ortak özelliklerinin ise "sürekli inovasyon ve kalite geliştirebilme gücü" olduğu sonucuna ulaşmıştır. Rekabet avantajı sağlayan bu başarı faktörlerini sürekli geliştirmek ve iyileştirmek en az sahip olmak kadar önemlidir. Porter 'nn bu modeli dört temel faktör ve iki destek faktörden oluşmaktadır. Temel faktörler; Firma Stratejisi, Yapısı ve Rekabet, İlişkili ve Destek Endüstriler, Faktör Koşulları ve Talep Koşullarıdır. Destek Faktörleri ise; Devlet ve Şans faktörlerdir.

Turizm literatüründe rekabet gücü çalışmaları ilk olarak 1990'lı yıllardan itibaren çalışılmaya başlanmıştır. Farklı yazarlar, turizm destinasyonlarının rekabetçi yapılarını farklı bakış açılarıyla ele almışlar ve farklı modeller geliştirmişlerdir. (Ritchie ve Crouch, 1999; 2003; Kim, 2000; Hassan, 2000; Dwyer ve Kim, 2003; Heat, 2003; Bahar ve Kozak, 2005; Azzopardi ve Nash, 2015; Sanchez ve Lopez, 2015). Ülkelerin turizmdeki rekabet güçleri çok sayıda faktör içermesi nedeniyle ölçümü oldukça zor olan bir konudur. Bu konudaki en kapsamlı çalışmalar ilk olarak Dünya Ekonomik Forumu tarafından 2007 yılında gerçekleştirilen ve ardından iki yılda bir kez tekrarlanan ve son olarak 2019 yılında 141 ülkenin rekabet faktörlerinin karşılaştırıldığı Seyahat ve Rekabetçilik endeksidir.

Turizm destinasyonlarının rekabet gücü, destinasyonların yaşam döngüsüne bakılmaksızın, turizm faaliyetlerine devam edebilmesi ve turizmin sürdürülebilirliği için hayati öneme sahiptir. Destinasyonların sürdürülebilir bir başarı elde etmesinin temel şartı rekabet faktörlerini sürekli geliştirmektir (Caldito, Rivero ve Paulido, 2014: 426). Destinasyon rekabetçiliği pazar talebine tutarlı bir şekilde değer katmakla ilgilidir. Destinasyonun sürdürülebilir bir rekabetçi pozisyon 
geliştirmesi, pazardaki talebin değişen yapısına da uyum sağlamakla mümkün olmaktadır (Hassan, 2000: 240).

Destinasyon rekabetçiliği konusunda yapılan tanımlara baktığımızda oldukça farklı tanımlar ile karşılaşmak mümkündür. D’Hauteserre (2000:23) destinasyon rekabetçiliğini “Bir destinasyonun pazardaki konumunu sürdürebilme ya da zaman içerisinde iyileştirebilme becerisidir" şeklinde tanımlarken, Hassan (2000: 239-240) ise, "Bir destinasyonun turizmdeki pazar payın korurken ayn zamanda doğal kaynaklarını da koruyarak değer yaratabilme yeteneği" olarak tanımlamaktadır. Dwyer ve Kim, (2003: 375) "Turistler için önemli olan mal ve hizmetleri daha iyi performans göstererek diğer destinasyonlardan daha iyi gerçekleştirebilme yeteneğì" olarak tanımlarken, Hong (2009: 109) ise, "Ziyaretçiler tarafindan önemli olduğu düşünülen katma değerli mal ve hizmetler de dahil olmak üzere turizm deneyimi oluşturabilme ve sunabilme yeteneği" şeklinde tanımlamaktadır.

Dupeyras ve MacCallum (2013: 7) destinasyon rekabetçiliğini “Bir destinasyonun yerel halkı ve ziyaretçilerine yönelik sahip olduğu çekicilikleri optimum düzeye çıkararak kaliteli, etkileyici ve yenilikçi turizm hizmetleri sunma becerisinin yanı sıra iç ve dış turizm pazarında pazar payını arttırmak ve destek kaynakların temin edilmesini sağlarken, turizmin sürdürülebilir gelişimini arttırmaktır" şeklinde tanımlamaktadır. Son olarak, UNWTO (2018: 16) destinasyon rekabetçiliğini, "Destinasyonların doğal, kültürel, insan ve insan yapımı kaynaklarımı, sürdürülebilir bir büyüme sağlamak için kaliteli, yenilikçi, etik ve cazip turizm ürün ve hizmetlerini geliştirmek ve sunmak için verimli bir şekilde kullanabilme yeteneğidir" şeklinde tanımlamaktadır.

Ritchie ve Crouch' a (2003: 2) göre bir destinasyonu rakiplerinden daha rekabetçi konuma getiren en önemli faktörler; turizme yönelik yapılan harcamaların yanı sıra ziyaretçilerine doyurucu deneyimler sunmak daha fazla ziyaretçi çekebilmek, yerel halkın refahını arttıracak çalışmalar yapmak ve doğal çevreyi gelecek nesiller adına korumaktır. Enright ve Newton'a (2004: 778) göre en rekabetçi destinasyon; potansiyel turistleri çekebilen ve gerçekleşen ziyaretler sonucu turistlerde tatmin yaratan destinasyonlar en rekabetçi destinasyonlardır. Ancak bu rekabet gücü, hem turizm hizmet sağlayıcıları olan destek faktörlerine hem de daha geniş bir dizi faktöre bağlıdır.

Destinasyon rekabetçiliğinin ölçümü konusundaki çalışmaları genel olarak birincil veriler ve ikincil veriler olmak üzere iki grupta incelemek mümkündür. Birincil veriler; araştırmacının ele aldığı konuya yönelik ihtiyaç duyduğu verileri doğrudan derlemesi yoluyla (anket, mülakat, gözlem) elde edilen verilerdir. İkincil veriler ise; farklı amaçlarla daha önce derlenmiş veri setleridir (Coşkun vd., 2017: 79-84). Yazılı ve yazılı olmayan belgeler, alan ve zaman serisi çalışmaları, sayımlar ve kurum anketleri ikincil verilere örnektir.

Birinci grupta çeşitli araştırmacılar tarafından toplanan birincil veriler ile yapılan çalışmalar yer almaktadır (Kozak ve Rimmington, 1999; Heath, 2003; Enright ve Newton, 2004; Bahar ve Kozak, 2007; Gomezelj ve Mihalic, 2008; Kozak vd., 2009; Çelik, 2014; Dwyer vd., 2014; Maravic vd., 2015; Sanchez ve Lopez, 2015; Sert ve Şahbaz, 2017; Albayrak vd., 2018; Perna vd., 2018; Patti, 2019). Konuyla ilgili daha önce yapılan bu tür çalışmalarda, destinasyonlara yönelik çeşitli nitelikler belirlenerek, turistlerin bu niteliklere göre deneyimledikleri destinasyonları değerlendirmeleri ya da yorum yapmaları istenmekte ve rekabetçilik düzeyi bu şekilde kıyaslanarak ölçülmektedir. Bu tür bir yaklaşım, destinasyon rekabetçiliği konusunda birincil veriler sağlamasına rağmen, yapılan çalışmalar arasında bir karşılaştırma imkânı sağlamamaktadır. Çünkü bu çalışmaların büyük bir çoğunluğunda ya tek bir destinasyon incelenmiş ya da rekabetçilik düzeyini ölçmek için her araştırmacı tarafından farklı nitelikler kullanılmıştır.

İkinci grupta ise çeşitli kurumlar tarafından yayınlanan ikincil veriler kullanılarak yapılan çalışmalar yer almaktadır (Gürsoy vd., 2009; Ivanov ve Webster, 2013; Hassan ve Uşaklı, 2013; Leung ve Baloğlu, 2013; Croes ve Kubickova, 2013; Göral, 2016; 2017; Özyurt ve Kantarc1, 2017). 
İkincil veriler kullanılarak yapılan bu tür çalışmalarda, aynı nitelikler niceliksel olarak daha fazla destinasyon için incelenmektedir. Bu sebeple endeksler kullanılarak yapılan çalışmalar, destinasyonlar arasında karşılaştırma imkânı sağlamaktadır. Çalışmalarda yazarların endeksler içerisinde en fazla yararlandıkları endeks ilk kez 2007 yılında Dünya Ekonomik Forumu tarafından yayınlanan Seyahat ve Turizm Rekabetçilik Endeksi olmuştur.

\section{YÖNTEM}

Araştırmanın amacı, Antalya iline bağlı Alanya ve Kemer turizm destinasyonlarının rekabet faktörlerine göre güçlü ve zayıf yönlerini belirlemek, Alanya ve Kemer destinasyonlarının rekabet güçlerini karşılaştırmaktır. Araştırma sorularının hazırlanması, yanıtlanması ve sonuçların yorumlanması sürecinde nicel araştırma yöntemleri uygulanmıştır. Araştırmada Bahar (2004) tarafından geliştirilen, Bahar ve Kozak (2005; 2007), Kozak vd., (2009) ve Çelik'in (2014) çalışmalarında da son halini alan "Destinasyon Rekabet Gücü Ölçeği”" kullanılmıştır. İki kıyı kentinin seçilmesinin temel nedeni, benzer turizm ürünleri sunuyor olmalarının yanı sıra, turizmin tarihsel gelişimine bakıldığında gelişim süreçlerinin birbirine paralel ilerlemiş olmasıdır. Araştırmanın evreni, Antalya iline bağlı Alanya ve Kemer turizm destinasyonlarını 2019 yılı Haziran, Temmuz, Ağustos, Eylül ve Ekim aylarında ziyaret eden yabancı turistlerden oluşmaktadır. Araştırmanın örneklemi ise, 2019 yılı Haziran, Temmuz, Ağustos, Eylül ve Ekim aylarında Alanya ve Kemer turizm destinasyonlarında tatillerinin son günlerini geçirenler ile turizm literatüründe "repeater" olarak adlandırılan, destinasyona tekrar gelen yabancı ziyaretçiler araştırmanın örneklemini oluşturmaktadır.

Kültür ve Turizm Bakanlığı'nın aylara göre gecelemelerin en fazla yaşandığı dönemler incelendiğinde araştırmanın yapılmasının planlandığı yaz aylarında olduğu görülmüştür. Sekaran'a (2003: 297) göre 75.000'in altında bir oranda bir evren için minimum örneklem sayısı $382,1.000 .000$ ve üzeri bir oranda bir evren için minimum örneklem sayısı ise 384'tür. Bu bilgilerden hareketle örneklem sayısının 400 ve üzeri bir sayıda olması hedeflenmiştir. Araştırmada Alanya' daki katılımcılara toplam 280 adet anket formu dağıtılmış, 245 adet anketten geri dönüş alınmıştır. Kemer için ise, 300 adet anket formu dağıtılmış ve 250 anketten geri dönüş alınmıştır. Alanya'dan 203, Kemer'den ise 210 olmak üzere toplam 413 adet anketle analize devam edilmiştir. Araştırmanın en temel hipotezi Alanya ve Kemer destinasyonlarının rekabet faktörleri arasında anlamlı farklar bulunup bulunmadığını tespit etmektir. Araştırmanın alt hipotezleri ise;

H1: Katılımcıların ziyaret ettikleri destinasyonlara göre hizmet kalitesine yönelik algıları arasında anlamlı farklılıklar vardır.

H2: Katılımcıların ziyaret ettikleri destinasyonlara göre altyapı unsurlarına yönelik algıları arasında anlamlı farklılıklar vardır.

H3: Katılımcıların ziyaret ettikleri destinasyonlara göre turistik hizmetlere yönelik algıları arasında anlamlı farklılıklar vardır.

H4: Katılımcların ziyaret ettikleri destinasyonlara göre turistik olanaklara yönelik algıları arasında anlamlı farklılıklar vardır.

H5: Katılımcıların ziyaret ettikleri destinasyonlara göre fiziksel çevreye yönelik algıları arasında anlamlı farklılıklar vardır.

H6: Katılımciların ziyaret ettikleri destinasyonlara göre doğal ve kültürel çekiciliklere yönelik algıları arasında anlamlı farklılıklar vardır. 
Destinasyon rekabet gücü anketi örneklem grubu üzerinde uygulanmadan önce muhtemel ifade hatalarından kaçınmak amacıyla her iki destinasyonda aynı örneklem grubunu kapsayacak şekilde bir pilot çalışma yapılmıştır. Pilot çalışma araştırma kapsamı dışında tutulmuş olup her iki destinasyonu 2019 haziran ayında ziyaret eden ve tatillerinin son günlerini geçiren turistler ile turizm literatüründe "repeater" olarak bilinen destinasyona tekrar gelen turistlere uygulanmıştır. Yaklaşık 64 adet anket analize tabi tutulmuştur. Pilot çalışma sonrası, İngilizce ölçek formunun, Almanca ve Rusça dillerine de dil uzmanlarınca çevirileri yaptırılmıştır. Uzman kişilerle çevrilen ifadeler, örneklem üzerinde ön test yapılmış ve üç dilde de aynı anlama geldiği belirlenmiştir.

\section{BULGULAR}

Araştırmaya katılan katılımcıların demografik özelliklerine ilişkin bulgular Tablo 1'de verilmiştir. Bu sonuçlara göre araştırmaya katılanların \%49,2'si Alanya'dan, \%50,8'i ise Kemer destinasyonunu ziyaret eden turistlerden oluşmaktadır. Araştırmaya katılan turistlerin \%43,3'ü erkek, 56,7'si ise kadınlardan oluştuğu görülmektedir. Katılımcıların yaşları incelendiğinde, \%12,8'i 18-24 yaş, \%24'ü 25-34 yaş, \%22,5'i 35-44, \%23,2'si, 45-54, \%9,9'u, 55-64, \%7,5'i ise 65 yaş ve üzeri yaş aralıklarında oldukları görülmüştür. Katılımcıların milliyetleri incelendiğinde, \%16,5'i Alman, \%47,7'si Rus, \%2,7'si Hollandall, \%5,3'ü Danimarkalı, \%3,6'sı İsveçli, \%5,8'i Polonyalı, \%3,6'sı Çeklerden oluştuğu görülmektedir. Araştırmaya katılan turistlerin eğitim durumları incelendiğinde, $\% 6,8^{\prime} \mathrm{i}$ ilkokul, $\% 44,1^{\prime} \mathrm{i}$ lise, $\% 40,7^{\prime}$ si lisans, $\% 7,5^{\prime} \mathrm{i}$ ise lisansüstü eğitim alanlardan oluşmaktadır.

Tablo 1. Katılımcıların Demografik Dağılımları

\begin{tabular}{llllll}
\hline Destinasyon & $\mathbf{N}$ & $\mathbf{\%}$ & Eğitim Durumu & $\mathbf{N}$ & $\%$ \\
Alanya & 203 & 49,2 & Ilkokul & 28 & 6,8 \\
Kemer & 210 & 50,8 & Lise & 182 & 44,1 \\
Cinsiyet & $\mathbf{N}$ & $\mathbf{\%}$ & Lisans & 168 & 40,7 \\
Erkek & 179 & 43,3 & Lisansüstü & 35 & 7,5 \\
Kadın & 234 & 56,7 & Gelir Durumu & $\mathbf{N}$ & $\%$ \\
Yaş & $\mathbf{N}$ & $\mathbf{\%}$ & 1000 Euro'dan az & 154 & 37,3 \\
$18-24$ & 53 & 12,8 & 1001-2000 Euro & 115 & 27,8 \\
$25-34$ & 99 & 24,0 & 2001-3000 Euro & 69 & 16,7 \\
$35-44$ & 93 & 22,5 & 3001-4000 Euro & 60 & 13,1 \\
$45-54$ & 96 & 23,2 & 4001 Euro ve üzeri & 15 & 3,6 \\
$55-64$ & 41 & 9,9 & Konaklama Türü & $\mathbf{N}$ & $\%$ \\
65 ve üzeri & 31 & 7,5 & Yarım Pansiyon & 80 & 19,4 \\
Milliyet & $\mathbf{N}$ & $\mathbf{\%}$ & Her şey Dahil & 237 & 57,4 \\
Alman & 68 & 16,5 & Ultra Her şey Dahil & 76 & 18,4 \\
Rus & 197 & 47,7 & Sadece Oda & 20 & 4,8 \\
Hollandalı & 11 & 2,7 & Kalış Süresi & $\mathbf{N}$ & $\%$ \\
Danimarkalı & 22 & 5,3 & 1-7 gün & 163 & 39,5 \\
İsveçli & 15 & 3,6 & 8-14 gün & 208 & 50,4 \\
Polonyalı & 24 & 5,8 & 15-30 gün & 42 & 10,2 \\
Çek & 15 & 3,6 & & & \\
Diğer & 61 & 14,8 & & & \\
\hline
\end{tabular}


Tablo 4.1'e göre, araştırmaya katılanlar gelir durumlarına göre incelendiğinde, katılımcıların \%37,3'ü 1000 Euro'dan daha az, \%27,8'i 1001 ve 2000 Euro, \%16,7'si 2001 ve 3000 Euro, \%13,1'i 3001 ve 4000 Euro, \%3,6'sı ise, 4001 Euro ve üzeri gelire sahip oldukları görülmüştür. Araştırma katılan ziyaretçilerin konaklama türüne göre dağılımlarına bakıldığında, \%19.4'ü yarım pansiyon, $\% 57,4^{\prime}$ ü her şey dahil, \%18,4'ü ultra her şey dahil, \%4,8'i ise sadece oda şeklinde konaklamaktadır. Son olarak, katılımcıların kalış süresine göre dağılımlarına bakıldığında ise, \%39,5'i 1-7 gün, \%50,4'ü 8-14 gün, \%10,2'si ise 15-30 gün konaklayanlardan oluşmaktadır (Tablo 1).

Katılımcıların Alanya ve Kemer destinasyonlarının rekabet faktörlerine yönelik düşüncelerini öğrenmek amacıyla 23 ifadeden oluşan ölçek faktör analizine tabi tutulmuştur. Faktör analizi, aralarında ilişki bulunan çok sayıda değişkenden oluşan bir veri setine ait temel faktörlerin ortaya çıkarılarak araştırmacı tarafından veri setinde bulunan kavramlar arasındaki ilişkilerin daha kolay anlaşılmasına yardımcı olan bir analizdir (Coşkun vd., 2017: 270). Ölçeğin faktör analizi için uygun olup olmadığını tespit etmek için Kaiser-Meyer-Olkin ve Barlet testleri uygulanmıştır. Faktör analizi için Kaiser-Meyer-Olkin test sonuçlarının $.60^{\prime}$ tan yüksek çıkması beklenir. Barlett testi ise, değişkenler arasında ilişki olup olmadığını kısmi korelasyon kapsamında inceler (Büyüköztürk, 2018: 136). Araştırmada elde edilen KMO değeri ,90»,60 ve Barlett sonucu ,000 tespit edilmiştir. Bu bilgiler doğrultusunda veri setleri faktör analizi ve veri yapısından faktör çıkarma için uygundur (Tablo 2).

Rekabet gücü boyutlarının altı faktör altında toplandığı görülmektedir. Bu faktörler Altyapı, Hizmet Kalitesi, Doğal ve Kültürel Çekicilikler, Fiziksel Çevre, Turistik Hizmetler ve Turistik Olanaklardır. Faktörlerden "Altyapı" ve "Hizmet Kalitesi" boyutu orijinal ölçek ile paralel bir şekilde faktörlenirken "Doğal ve Kültürel Çekicilikler" ile "Turistik Faaliyet ve Aktiviteler" kendi aralarında 4 ayrı faktörden meydana geldiği tespit edilmiştir. Bu ifadeler ile ilgili literatür incelenerek "Turistik Hizmetler" ve "Turistik Olanaklar" adıyla yeniden isimlendirilmiştir. Faktör yük değerlerinin 0,30 ve 0,40 aralığında olması minimum seviyeyi karşılayabilmektedir (Hair, Black, Babin ve Anderson, 2014: 116). Faktör yük değerleri incelendiğinde tüm ifadelerin yük değerlerinin 0,40’ı üzerinde olduğu görülebilmektedir. Faktör analizi sonuçlarına göre 6 faktör varyansın toplam \%60.29'unu açıklamaktadır (Tablo 2).

Araştırma amacına yönelik doğru istatistiksel yöntemlerin seçilmesi amacıyla faktörler normallik analizine tabi tutulmuş ve normallik analizi sonucu normallik varsayımını sağlayan istatistiksel yöntemlerin kullanılması uygun görülmüştür.

Alanya'yı ziyaret eden turistlerin hizmet kalitesine ilişkin ortalama puanı $X=4,23$ ve Kemer'i ziyaret eden turistlerin hizmet kalitesine ilişkin ortalama puanı $X=4,10^{\prime}$ dur. Alanya'yı ziyaret eden turistler ile Kemer'i ziyaret eden turistlerin destinasyonlardaki hizmet kalitesine ilişkin algıları arasında anlamlı bir farklılık bulunmuştur, 0,021, p<0,05. Bir diğer deyimle, araştırmaya Alanya ve Kemer'den katılan turistlerin destinasyonlarda sunulan hizmet kalitesine ilişkin algıları anlamlı bir farklılığa yol açmıştır. Dolayısıyla H1 hipotezi kabul edilmiştir. Ayrıca bu bulguya göre, hizmet kalitesi açısından Alanya'nın Kemer'den daha rekabetçi olduğunun bir göstergesi olarak yorumlanabilir (Tablo 3). 
Tablo 2. Destinasyonlara İlişkin Aritmetik Ortalamalar ve AFA Sonuçları

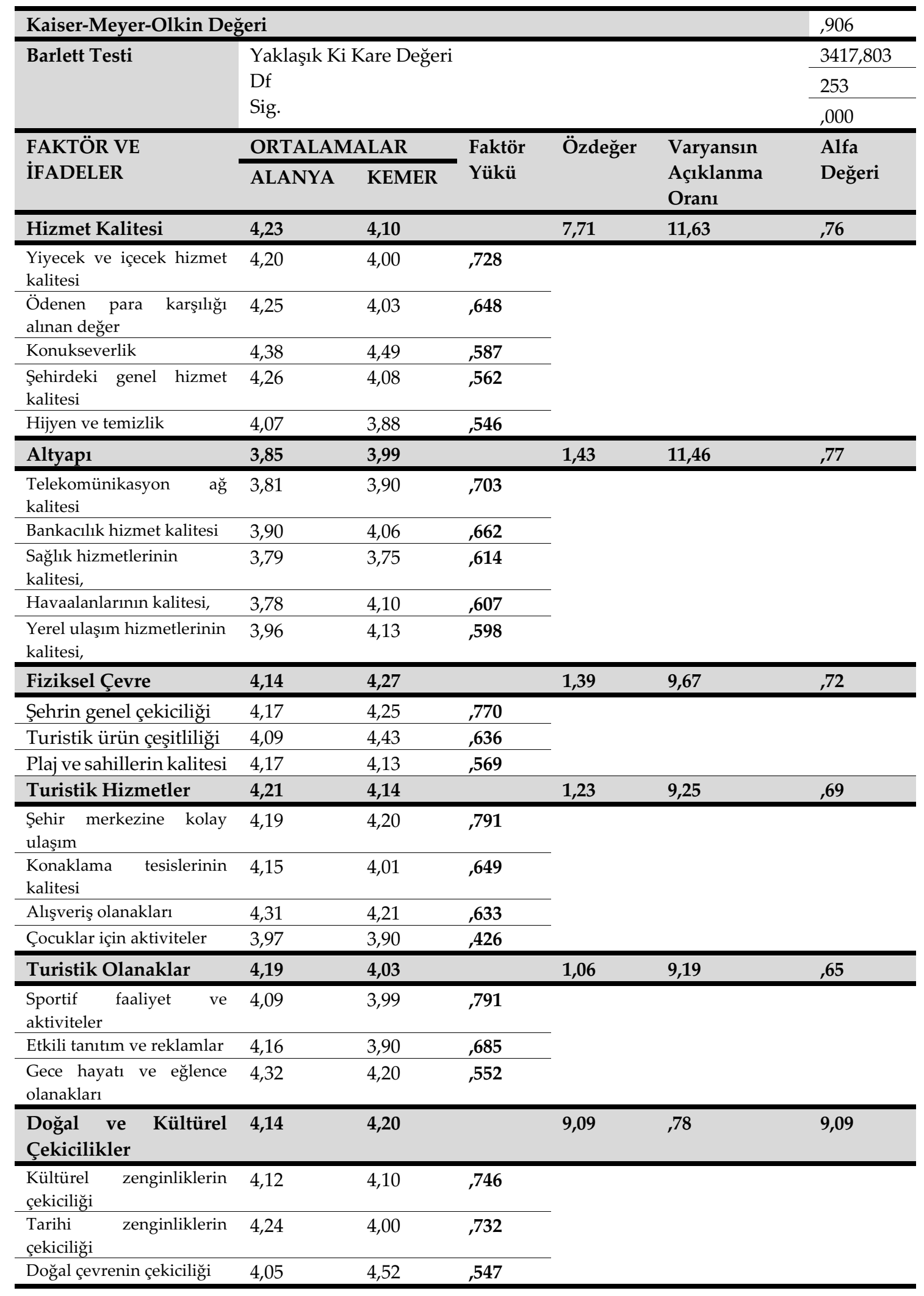


Tablo 3. Katılımcıların Ziyaret Ettikleri Destinasyonlara Göre Hizmet Kalitesine Yönelik Algılarına İlişkin T- testi Sonuçları

\begin{tabular}{lllllll}
\hline Faktör & Destinasyon & $\mathbf{N}$ & $\mathbf{X}$ & S.S. & $\mathbf{t}$ & $\mathbf{P}$ \\
\hline \multirow{3}{*}{ Hizmet Kalitesi } & Alanya & 203 & 4,2385 &, 58621 & 2,323 & 0,021 \\
& Kemer & 210 & 4,1068 &, 56601 & & \\
\hline
\end{tabular}

Alanya'yı ziyaret eden turistlerin altyapıya ilişkin ortalama puanı $X=3,85$ ve Kemer'i ziyaret eden turistlerin altyapıya ilişkin ortalama puanı $X=3,99^{\prime}$ dur. Alanya'yı ziyaret eden turistler ile Kemer'i ziyaret eden turistlerin destinasyonlardaki altyapı kalitesine ilişkin algıları arasında anlamlı bir farklılık bulunmuştur, 0,026, $\mathrm{p}<0,05$. Bir diğer deyimle, araştırmaya Alanya ve Kemer'den katılan turistlerin destinasyonlarda sunulan altyapı kalitesine ilişkin algıları anlamlı bir farklılığa yol açmıştır. Dolayısıyla H2 hipotezi kabul edilmiştir. Ayrıca bu bulguya göre, altyapı açısından Kemer'in Alanya'dan daha rekabetçi olduğunun bir göstergesi olarak yorumlanabilir (Tablo 4).

Tablo 4. Katılımcıların Ziyaret Ettikleri Destinasyonlara Göre Altyapı Unsurlarına Yönelik Algılarına İlişkin T- testi Sonuçları

\begin{tabular}{lllllll}
\hline Faktör & Destinasyon & $\mathbf{N}$ & $\mathbf{X}$ & S.S. & t & P \\
\hline & Alanya & 203 & 3,8522 &, 66849 & 2,242 & 0,026 \\
Altyap1 & Kemer & 210 & 3,9940 &, 61708 & & \\
\hline
\end{tabular}

Alanya'yı ziyaret eden turistlerin turistik hizmetlere ilişkin ortalama puanı $X=4,21$ ve Kemer'i ziyaret eden turistlerin turistik hizmetlere ilişkin ortalama puanı $X=4,14^{\prime}$ dur. Alanya'yı ziyaret eden turistler ile Kemer'i ziyaret eden turistlerin destinasyonlarda sunulan turistik hizmetlere ilişkin algıları arasında anlamlı bir farklılık bulunamamıştır, 0,194, p>0,05. Dolayısıyla H3 hipotezi reddedilmiştir (Tablo 5).

Tablo 5. Katılımcıların Ziyaret Ettikleri Destinasyonlara Göre Turistik Hizmetlere Yönelik Algılarına İlişkin T- testi Sonuçları

\begin{tabular}{lllllll}
\hline Faktör & Destinasyon & $\mathbf{N}$ & $\mathbf{X}$ & S.S. & $\mathbf{t}$ & $\mathbf{P}$ \\
\hline Turistik & Alanya & 203 & 4,2184 &, 52015 & 1,302 & 0,194 \\
Hizmetler & Kemer & 210 & 4,1468 &, 59528 & & \\
\hline
\end{tabular}

Alanya'yı ziyaret eden turistlerin turistik olanaklara ilişkin ortalama puanı $X=4,19$ ve Kemer'i ziyaret eden turistlerin turistik olanaklara ilişkin ortalama puanı $X=4,03^{\prime}$ dür. Alanya'yı ziyaret eden turistler ile Kemer'i ziyaret eden turistlerin destinasyonlarda sunulan turistik olanaklara ilişkin algıları arasında anlamlı bir farklılık bulunmuştur, 0,004, $\mathrm{p}<0,05$. Bir diğer deyimle, araştırmaya Alanya ve Kemer'den katılan turistlerin destinasyonlarda sunulan turistik olanaklara ilişkin algıları anlamlı bir farklılığa yol açmıştır. Dolayısıyla H4 hipotezi kabul edilmiştir. Ayrıca bu bulguya göre, turistik olanaklar açısından Alanya'nın Kemer'den daha rekabetçi olduğunun bir göstergesi olarak yorumlanabilir (Tablo 6). 
Tablo 6. Katılımcıların Ziyaret Ettikleri Destinasyonlara Göre Turistik Olanaklara Yönelik Algılarına İlişkin T-testi Sonuçları

\begin{tabular}{lllllll}
\hline Faktör & Destinasyon & $\mathbf{N}$ & $\mathbf{X}$ & S.S. & $\mathbf{t}$ & $\mathbf{P}$ \\
\hline Turistik & Alanya & 203 & 4,1918 &, 50521 & 2,871 & 0,004 \\
Olanaklar & Kemer & 210 & 4,0362 &, 59405 & & \\
\hline
\end{tabular}

Alanya'yı ziyaret eden turistlerin fiziksel çevre unsurlarına ilişkin ortalama puanı $X=4,14$ ve Kemer'i ziyaret eden turistlerin fiziksel çevre unsurlarına ilişkin ortalama puanı $X=4,27$ 'dir. Alanya'yı ziyaret eden turistler ile Kemer'i ziyaret eden turistlerin destinasyonlarda bulunan fiziksel çevre unsurlarına ilişkin algıları arasında anlamlı bir farklılık bulunmuştur, 0,047, p<0,05. Bir diğer deyimle, araştırmaya Alanya ve Kemer'den katılan turistlerin destinasyonlarda bulunan fiziksel çevre unsurlarına ilişkin algıları anlamlı bir farklılığa yol açmıştır. Dolayısıyla H5 hipotezi kabul edilmiştir. Ayrıca bu bulguya göre, fiziksel çevre unsurları açısından Kemer'in Alanya'dan daha rekabetçi olduğunun şeklinde yorumlanabilir (Tablo 7).

Tablo 7. Katılımcıların Ziyaret Ettikleri Destinasyonlara Göre Fiziksel Çevreye Yönelik Algılarına İlişkin T- testi Sonuçları

\begin{tabular}{lllllll}
\hline Faktör & Destinasyon & $\mathbf{N}$ & $\mathbf{X}$ & S.S. & $\mathbf{t}$ & $\mathbf{P}$ \\
\hline Fiziksel Çevre & Alanya & 203 & 4,1478 &, 69340 & 1,993 & 0,047 \\
& Kemer & 210 & 4,2779 &, 63274 & & \\
\hline
\end{tabular}

Alanya'yı ziyaret eden turistlerin doğal ve kültürel çekiciliklere ilişkin ortalama puanı $X=4,14$ ve Kemer'i ziyaret eden turistlerin doğal ve kültürel çekiciliklere ilişkin ortalama puanı $X=4,20^{\prime}$ dir. Alanya'yı ziyaret eden turistler ile Kemer'i ziyaret eden turistlerin destinasyonlarda bulunan doğal ve kültürel çekiciliklere ilişkin algıları arasında anlamlı bir farklılık bulunamamıştır, 0,356, p>0,05. Dolayısıyla H6 hipotezi reddedilmiştir (Tablo 8).

Tablo 8. Katılımcıların Ziyaret Ettikleri Destinasyonlara Göre Doğal ve Kültürel Çekiciliklere Yönelik Algılarına İlişkin T- testi Sonuçları

\begin{tabular}{lllllll}
\hline Faktör & Destinasyon & $\mathbf{N}$ & $\mathbf{X}$ & S.S. & $\mathbf{t}$ & P \\
\hline Doğal ve Kültürel Çekicilikler & Alanya & 203 & 4,1429 &, 72883 & $-0,924$ & 0,356 \\
& Kemer & 210 & 4,2079 &, 70212 & & \\
\hline
\end{tabular}

Araştırma sonucunda destinasyon rekabet gücü ölçeğine göre Alanya ve Kemer turizm destinasyonlarının rekabet faktörleri toplam 4 faktörde farklılaşırken, 2 faktörde bir farklılık görülmemiştir. Hizmet kalitesi ve turistik olanaklar açısından Alanya, altyapı ve fiziksel çevre açısından ise Kemer'in daha rekabetçi olduğu sonucuna ulaşılmıştır.

\section{TARTIŞMA, SONUÇ ve ÖNERİLER}

Bu çalışmada Türkiye'nin güney kıyılarında yer alan Alanya ve Kemer turizm destinasyonlarının rekabet faktörlerinin ziyaretçi bakış açısıyla karşılaştırılması amaçlanmıştır. Araştırmada Bahar (2004) tarafından geliştirilen destinasyon rekabet gücü ölçeği kullanılmıştır. Turistik Faaliyet ve Aktivite Olanakları, Doğal ve Kültürel Çekicilikler, Hizmet Kalitesi ve Altyapı şeklinde olan 
faktörler, açıklayıcı faktör analizi sonucu 6 faktör olarak ortaya çıkmıştır. Altyapı ve Hizmet kalitesi orijinal ölçek ile uyumlu bir şekilde dağılım gösterirken, doğal ve kültürel çekicilikler ve turistik faaliyet ve aktivite olanakları kendi içinde farklı birer yapı daha barındırdığı görülmüştür. Doğal ve kültürel çekicilikler iki farklı faktöre ayrıldığı görülmüş ve diğer faktör fiziksel çevre adıyla yeniden isimlendirilmiştir. Turistik faaliyet ve aktivite olanaklarının da iki faktöre ayrıldığı görülmüş ve turistik hizmetler ve turistik olanaklar adıyla yeniden isimlendirilmiştir. Bu durum şöyle açıklanabilir, Ritchie ve Crouch'un (2003) çalışmasında temel kaynak ve çekicilikler temel faktörü altında destinasyonun kültür ve tarihi ile destinasyondaki, fiziksel çevre ve iklimin bir diğer alt çekicilik faktörü olduğu görülmüştür. Araştırmada turistik hizmetler ve turistik olanaklar olarak iki faktöre ayrılan Turistik faaliyet ve aktivite olanakları Ön Esen ve Kılıç'ın (2017) çalışmasında da turistik hizmetler ve turistik olanaklar alt faktörleri olarak ayrıldığı görülmüş. Ön Esen ve Kılıç'ın (2017) çalışmasında gece hayatı ve eğlence olanakları ile sportif faaliyet ve aktiviteler turistik olanaklar faktörü altında, şehir merkezine kolay ulaşım ve konaklama tesislerinin kalitesi turistik hizmetler faktörü altında toplanmıştır.

"Gece hayatı ve eğlence olanakları" her iki destinasyonda da en fazla öne çıkan değişkenler olmuştur. Albayrak vd., (2018)'nin çalışmasında da Antalya'nın gece hayatı ve eğlence olanakları açısından önde olduğu görülmüştür. "Konukseverlik" her iki destinasyonda da en fazla öne çıan bir diğer değişken olmuştur. Maravic vd., (2015) de çalışmalarında kıyı destinasyonu olan Opatja'nın en önemli faktörünün konukseverlik olduğunu tespit etmişlerdir. Bu bulgudan hareketle kıyı destinasyonları için konukseverlik önemli bir faktördür. Her iki destinasyonda öne çıan bir diğer değişken ise "Doğal ve kültürel çekiciliklerdir." Bahar ve Kozak'a (2007) göre de destinasyonların en önemli unsuru doğal ve kültürel çekicilikler olurken hem ziyaretçiler hem de destinasyondaki hizmet sağlayıcıların doğal ve kültürel çekiciliklere ilişki algıları arasında pozitif korelasyon olduğunu tespit etmişlerdir. Eğitim, yaş, gelir durumu, konaklama türü değişkenlerine göre de rekabet faktörlerine ilişkin algıları arasında farklılıklar olduğu görülmüştür. Eğitim durumu değişkeni açısından Kemer destinasyonunda rekabet faktörlerine yönelik algılamalara ilişkin farklar görülmesine karşın Alanya destinasyonunda ise bir farklılık görülmemiştir. Alanya destinasyonunda ilkokul mezunu katılımcıların da yer aldığı görülürken, Kemer destinasyonunda ilkokul mezunu katılımcıya rastlanmamıştır. Sert ve Şahbaz'ın (2017) Ankara bölgesindeki tesislerde yapmış olduğu çalışmada ise eğitim düzeyinin rekabet faktörleri üzerinde etkili olduğu görülmüş ancak lisansüstü mezunlarının daha alt eğitim düzeyindeki katılımcılara göre rekabet faktörlerine yönelik algılarının daha yüksek olduğu görülmüsştür.

Katılımcıların yaşlarına yönelik bulgular incelediğinde 55-64 yaş arası katılımcılar Kemer'in altyapısının yeterli olmadığını düşünmektedirler. Ancak 35 ve 44 yaş arası katılımcılar, hizmet kalitesi, fiziksel çevre, doğal ve kültürel çekicilikler, turistik olanaklar ve turistik hizmetler açısından Kemer' in oldukça yeterli olduğunu düşünmektedir. Alanya destinasyonunda bulunan 65 ve üzeri yaş grubundaki katılımcılar ise, Alanya'nın doğal ve kültürel çekim unsurlarının yetersiz olduğunu düşünmektedirler. Katılımcıların gelir durumuna göre rekabet faktörlerine yönelik algıları incelendiğinde 2001 Euro ve üzeri gelire sahip turistler Kemer'in altyapısının daha az gelire sahip turistlere göre daha orta düzeyde olduğunu düşünmektedirler. Katılımcların konaklama türüne göre destinasyon rekabet faktörlerine yönelik algıları incelendiğinde Alanya bölgesinde sadece oda şeklinde konaklayanlar diğer konaklama seçeneklerini tercih edenlere göre Alanya'nın altyapısının oldukça iyi olduğunu düşünmektedirler.

Destinasyon rekabet gücü ölçeğine göre Alanya ve Kemer turizm destinasyonlarının rekabet faktörleri toplam 4 faktörde farklılaşırken, 2 faktörde bir farklılık görülmemiştir. Hizmet kalitesi 
ve turistik olanaklar açısından Alanya, altyapı ve fiziksel çevre açısından ise Kemer'in daha rekabetçi olduğu görülmüştür.

Araştırmanın amacına yönelik destinasyon rekabet faktörleri açısından Alanya ve Kemer destinasyonlarının karşılaştırılmasına ilişkin bulgular ve bu bulguların demografik değişkenlere yönelik sonuçları literatürdeki bazı bulgulara göre aşağıda verilmiştir.

- Destinasyonların rekabet faktörleri, temel boyutlar altında incelendiğinde, yaklaşık 4 faktörde farklılık görülmektedir. Hizmet kalitesi ve turistik olanaklar açısından Alanya Kemer'den daha rekabetçi iken, altyapı ve fiziksel çevre açısından ise Kemer Alanya'dan daha rekabetçidir. Faktörlerin alt boyutları açısından incelendiğinde, toplam 14 değişkende Alanya'nın daha önde olduğu görülürken, 9 değişkende ise Kemer daha öndedir. Değişkenler arasında konukseverlik 4,38 ile Alanya'nın faktörlere göre en fazla puana sahip olduğu değişken olduğu görülürken, doğal çekiciliklerin zenginliği ise, 4,52 ile Kemer'in en fazla puana sahip olduğu değişken olduğu görülmektedir.

- Destinasyon rekabetçiliğine yönelik ifadeler incelendiğinde hem Alanya hem de Kemer destinasyonuna yönelik ifadeler genel anlamda olumludur. 5 alt faktörden oluşan "Hizmet Kalitesi" açısından Alanya ve Kemer destinasyonuna yönelik ortalamalar incelendiğinde Alanya'nın Kemer'den daha rekabetçi olduğu görülürken, her iki destinasyonun ortalamalarının birbirlerine yakın olduğu ve Kemer bölgesinin de hizmet kalitesi açısından rekabet gücünün yüksek olduğu söylenebilir. 5 alt faktörden oluşan "Altyapı" açısından Alanya ve Kemer'in ortalamaları incelendiğinde Kemer'in Alanya'dan daha rekabetçi olduğu görülürken, her iki destinasyonun ortalamalarının birbirlerine yakın olduğu ve Alanya'nın da altyapı açısından rekabetçi olduğu söylenebilir. Altyapının alt faktörleri arasında yer alan "Yerel ulaşım hizmetleri", her iki destinasyonda da en fazla ön plana çıan faktör olmuştur.

- "Fiziksel çevre" açısından her iki destinasyon incelendiğinde, Alanya ve Kemer arasında 0,05 güven aralığında, 0,047 düzeyinde bir farklılık görülmekte ve Kemer'in rekabette daha önde olduğu görülmektedir. Fiziksel çevrenin alt faktörleri arasında yer alan "Plaj ve sahillerin kalitesi" Alanya'da en fazla öne çıkan faktör olurken, "Turistik ürün çeşitliliği" ise Kemer'de en fazla öne çıan faktör olmuştur. "Turistik hizmetler" açısından her iki destinasyon arasında anlamlı bir farklılık görülmemiştir. Turistik olanaklar açısından ise Alanya'nın Kemer'den daha rekabetçi olduğu görülmektedir. 3 alt faktörden oluşan turistik olanaklarda, "Alışveriş olanakları" her iki destinasyonda da en fazla öne çıkan değişkendir. Ziyaretçi yorumlarına göre "Doğal ve Kültürel Çekicilikler" açısından ise, her iki destinasyon arasından anlamlı bir farklılık görülmemiştir. Doğal ve kültürel çekicilikler açısından Alanya'da en fazla öne çıkan ifade, "Tarihi zenginliğin çekiciliği" olurken, Kemer'de en fazla öne çıan ifade ise, "Doğal zenginliğin çekiciliăgi" olduğu görülmüştür.

Araştırma bulguları incelendiğinde Alanya bölgesini farklı milliyetlerden ziyaretçilerin geldiği hem bulgular sonucu hem de araştırma esnasında gözlemlenmesine karşın, Kemer bölgesinin çoğunlukla Rus pazarına odaklandığı görülmüştür. Bu durum Rus turist talebinde yaşanacak muhtemel bir krizde Kemer destinasyonu için çeşitli riskler barındırmaktadır. Kemer destinasyonu ve Alanya destinasyonu katılımcılarının gelir durumları incelendiğinde Alanya'nın daha üst gelir grubuna hitap ettiği gözlemlenmiştir. Alışveriş olanaklarının oldukça yüksek olduğu görülen Kemer destinasyonuna daha üst gelir grubundan ziyaretçi çekmek turizm gelirinin yerel halka daha fazla katkı sağlamasına yol açacaktır. Havaalanları kalitesi açısından Kemer'in ortalamasının Alanya'nın önünde olduğu görülmüştür. Bunun nedeninin Alanya-Gzp havalimanın küçük ve havalimanı içi alışveriş olanaklarının kısıtlı olmasından ve Antalya havalimanını kullanan katılımcılar açısından ise Alanya'ya uzaklığından kaynaklandığ 
düşünülmektedir. Ayrıca Kemer destinasyonunun Altyapı açısından Alanya'nın önünde görülmesi Kemer'in çok daha kaliteli bir altyapıya sahip olduğu anlamına gelmemelidir.

Turizm destinasyonlarının rekabet güçlerini ortaya koymak ve geri planda kalan faktörlere önem vererek iyileştirmek, sürdürülebilir turizm gelişimi açısından önem taşımaktadır. Rekabet faktörlerini sürekli geliştiren, iyileştiren ve alternatif turizm ürünleri sunarak turizm pazarını çeşitlendiren destinasyonlar krizleri daha az hasarla atlatabilmektedir. Her türlü iç ve dış kaynaklı krizden etkilenen ülkemizin en önemli kıyı destinasyonları arasında bulunan Alanya ve Kemer, altyapı, hizmet kalitesi, turistik hizmetler, turistik olanaklar, doğal ve kültürel çekicilikler ve fiziksel çevre unsurlarını sürdürülebilir bir şekilde iyileştirmeli ve geliştirmelidir.

Gelecek çalışmalar açısından ise, benzer çalışmaların yerli turistlere yönelik olarak yapılmasıdır. Ayrıca, gelecek çalışmaların farklı kıyı destinasyonlarında da yapılması önerilmektedir. Destinasyonların rekabet güçlerinin sadece talep bakış açısı ile değil aynı zamanda arz bakış açısıyla ölçümlenmesi gerekmektedir. Bunun yanı sıra tek bir kıyı destinasyonunun birden fazla destinasyona yönelik rekabetçi konumunun yerli ve yabancı turistlerin bakış açıları ile incelenmesi ve AHP, TOPSIS, PROMETHEE, ELECTRE, MOORA, Veri Zarflama Yöntemi, Önem Performans Analizi gibi çok değişkenli karar verme yöntemleriyle de ölçümler yapılması tavsiye edilmektedir.

\section{KAYNAKÇA}

Albayrak, T., Caber, M., Gonzalez-Rodrigez, M., and Aksu, A. (2018). Analysis of Destination Competitiveness by IPA and IPCA Methods: The Case of Costa Brava, Spain Against Antalya, Turkey. Tourism Management Perpectives, 28: 3-61.

Andrades, L., and Dimanche, F. (2019). Destination Competitiveness in Russia: Tourism Professionals Skills and Competences. International Journal of Contemporary Hospitality Management. 31(2): 910-930.

Armenski, T., Dwyer, L. and Pavluković, V. (2017). Destination Competitiveness: Public and Private Sector Tourism Management in Serbia. Journal of Travel Research, 57(3): 384-398.

Azzopardi, E. and Nash, R. (2015). A Framework for Island Destination CompetitivenessPerspectives from the Island of Malta. Current Issues in Tourism, 19(3): 1-29.

Bahar, O. (2004). Türkiye'de Turizm Sektörünün Rekabet Gücü Analizi Üzerine Bir Alan Araştırması: Muğla Örneği, (Yayımlanmamış Doktora Tezi). Muğla Üniversitesi, Muğla.

Bahar, O. and Kozak, M. (2007). Advancing Destination Competitiveness Research: Comparison Between Tourists and Service Providers. Journal of Travel and Tourism Marketing, 22(2): 61-71.

Bahar, O. ve Kozak, M. (2005). Küreselleşme Sürecinde Uluslararası Turizm ve Rekabet Edebilirlik. (1.Baskı). Ankara: Detay Yayıncilık.

Büyüköztürk, Ş. (2018). Sosyal Bilimler İçin Veri Analizi El Kitabı: İstatistik, Araştırma Deseni, SPSS Uygulamaları ve Yorum. (24. Baskı). Ankara: Pegem Akademi. 
Caldito, A, L., Sanchez Rivero, M., and Paulido Fernandez, J, I. (2014). Tourism Destination Competitiveness from A Demand Point of View: An Empirical Analysis for Andulusia. Tourism Analysis, 19: 425-440.

Coşkun, R., Altunışık, R., ve Yıldırım, E. (2017). Sosyal Bilimlerde Araştırma Yöntemleri. (9. Baskı). Sakarya: Sakarya Yayıncllı.

Croes, R., and Kubickova, M. (2013). From Potential to Ability to Compete: Towards A Performance-Based Tourism Competitiveness Index. Journal of Destination Marketing and Management, 2(3): 146-154.

Çelik, P. (2014). Antalya Turizm Destinasyonunun Rekabetçilik Analizi, (Yayımlanmamış Doktora Tezi). Akdeniz Üniversitesi, Antalya.

Demir, C. ve Çevirgen, A. (2006). Turizm ve Çeore Yönetimi: Sürdürülebilir Gelişme Yaklaşımı. (1. Baskı). Ankara: Nobel Yayıncılık.

D'Hauteserre, A, M. (2000). Lessons in Managed Destination Competitiveness: The Case of Foxwoods Casino Resort. Tourism Management, 21: 23-32.

Dwyer, L., Dragicevic, V., Armenski, T., Mihalic, T., Mihalic, T., and Cvelbar, K, L. (2014). Achieving Destination Competitiveness: An Importance Performance Analysis of Serbia. Current Issues in Tourism, 17(1): 1-28

Dwyer, L., Mellor, R., Livaic, Z., Edwards, D., and Kim, C. (2004). Attributes of Destination Competitiveness: A Factor Analysis. Tourism Analysis, 9(1), 91-101.

Dwyer, L. and Kim, C. (2003). Destination Competitiveness: Determinants and Indicators. Current Issues in Tourism, 6(5): 369-414.

Enright, M, J. and Newton, J. (2004). Tourism Destination Competitiveness: A Quantitative Approach. Tourism Management, 25: 777-788.

Fernández, J.S. A., Serdeira Azevedo, P., Martín Martín, J. M., and Rodríguez Martín, J. A. (2020). Determinants of Tourism Destination Competitiveness in The Countries Most Visited by International Tourists: Proposal of A Synthetic Index. Tourism Management Perspectives, 33: 1-13.

Goffi, G., Cucculelli, M., and Masiero, L. (2018). Fostering Tourism Destination Competitiveness in Developing Countries: The Role of Sustainability. Journal of Cleaner Production. 209: 101-115.

Gomezelj, O, D. and Mihalic, T. (2008). Destination Competitiveness: Applying Different Models, The Case of Slovenia. Tourism Management, 29: 294-307.

Göral, R. (2016). Price Competitiveness of International Tourism Destinations and Tourism Demand, Tourism Receipts Relationship. European Journal of Multidisciplinary Studies, 1(2): 195203. 
Gürsoy, D., Baloglu, Ş., and Chi, C, G. (2009). Destination Competitiveness of Middle Eastern Countries: An Examination of Relative Positioning. An International Journal of Tourism and Hospitality Research, 20(1): 151-163.

Hair, J, F, H., Black, C, W., Babin, J, B., and Anderson, E, R. (2014). Pearson New International Edition: Multivariate Data Analysis. (7th ed.). Edinburg: Pearson Education Limited.

Hassan, S. S. (2000). Determinants of Market Competitiveness in An Environmentally Sustainable Tourism Industry. Journal of Travel Research, 38(3): 239-245.

Hassan, A. ve Uşaklı, A. (2013). Seyahat ve Turizm Rekabetçilik Endeksi: Akdeniz Çanağındaki Destinasyonlara Yönelik Karşılaştırmalı Bir Analiz. Seyahat ve Otel İşletmeciliği Dergisi, 10(2): 5367.

Heath, E. (2003). Towards a Model to Enhance Destination Competitiveness: A Southern African Perspective. Journal of Hospitality and Tourism Management, 10(2), 327-353.

Hong, W, C. (2009). Global Competitiveness Measurement for The Tourism Sector. Current Issues in Tourism, 12(2): 105-132.

Ivanov, S. and Webster, C. (2013). Globalisation as a Driver of Destination Competitiveness. Annals of Tourism Research, 43: 624-650.

Kim, C. (2000). A Model Development for Measuring Global Competitiveness of the Tourism Industry in the Asia-Pasific Region. (Unpublished Ph.D. Thesis). Korea Institute for International Economic Policy, Korea.

Kozak, M., Baloglu, Ş. and Bahar, O. (2009). Measuring Destination Competitiveness: Multiple Destinations Versus Multiple Nationalities. Journal of Hospitality Marketing and Management, 19(1): 56-71.

Kozak, M. and Rimmington, M. (1999). Measuring Tourist Destination Competitiveness: Conceptual Considerations and Empirical Findings. Journal of Hospitality Management, 18: 273283.

Kayar, Ç. H., and Kozak, N. (2007). Measuring Destination Competitiveness: An Application of The Travel and Tourism Competitiveness Index. Journal of Hospitality Marketing and Management, 19(3): 203-216.

Kozak, M. and Baloglu, Ş. (2011). Managing and Marketing Tourist Destinations: Strategies to Gain a Competitive Edge. New York: Taylor and Francis.

Kubickova, M. (2017). The Impact of Government Policies on Destination Competitiveness in Developing Economies. Current Issues in Tourism, 1: 1-24.

Kocaman, S. (2020). Destinasyon Rekabetçiliği: 2019 Uluslararası Seyahat ve Turizm Rekabetçilik Endeksi Verileri Kapsamında Akdeniz Havzasında Yer Alan Destinasyonlara Yönelik Kümeleme Analizi. MTCON 2020. Kıtalararası Turizm Yönetimi Konferansı Bildiriler Kitabı. Detay Yayıncilik. Ankara. 
Leung, Y, X. and Baloğlu, Ş. (2013). Tourism Competitiveness of Asia Pacific Destinations. Tourism Analysis, 18: 371-384.

Maravic, M, U., Gracan, D., and Zadel. (2015). A Comparison of the Competitiveness of the Two Coastal Tourist Destinations. Nase More, 62(4): 120-126.

Nazmfar, H., Eshghei, A., Alavi, S., and Pourmoradian, S. (2019) Analysis of Travel and Tourism Competitiveness Index in Middle-East Countries, Asia Pacific Journal of Tourism Research, 24(6): 501-513.

Omerzel, D, G. (2006). Competitiveness of Slovenia As a Tourist Destination. Managing Global Transitions, 4(2): 167-189.

Özyurt, P, M. and Kantarc1, K. (2017). The Intervening Role of Competitiveness on the Relationship Between Sustainability and Tourism Performance: A Research on European Countries. Economic Themes, 55(1): 89-103.

Patti, S. (2019). Determinants of Tourist Destination Competitiveness in a Low-Carbon Tourism. Hashim, R., Hanafiah, M, H, M., Jamaluddin, M, R. (Ed.). Positioning and Branding Tourism Destinations for Global Competitiveness, Global Disseminator of Knowledge, p. 292.

Perna, F., Custodio, M, J., and Oliveira, V. (2018). Tourism Destination Competitiveness: An Application Model for the South of Portugal Versus the Mediterranean Region of Spain: Competitivetour. Tourism and Management Studies, 14(1): 19-29.

Porter, M, E. (1990). The Competitive Advantage of Nations. (1 ${ }^{\text {sth }}$ Ed.). New York: Harvard Business Review.

Ritchie, J. R. B., and Crouch, G. I. (2010). A Model of Destination Competitiveness Sustainability: Brazilian Perspectives. Revista De Administração Pública, 44(5), 1049-1066.

Ritchie, J, R, B. and Crouch, G, I. (2003). The Competitive Destination: A Sustainable Tourism Perspective. London: CABI Publishing.

Sanchez, G, A. and Lopez, S, D. (2015). Tourism Destination Competitiveness: the Spanish Mediterranean Case. Tourism Economics, 21(6): 1235-1254.

Sekaran, U. (2003). Research Methods for Business: A Skill Building Approach. (4 $4^{\text {th }}$ Ed.). New York: John Wiley \& Sons, INC.

Sert, A, N. ve Şahbaz, R, P. (2017). Turist Bakış Açısıyla Destinasyon Rekabet Gücünün Belirlenmesinde Sosyo-Demografik Özelliklerin Etkisine Yönelik Bir Araştırma. Journal of Tourism and Gastronomy Studies, 5(3): 74-92.

Tokatlığlu, İ. (1999). İktisadi Analizde Rekabet Kavramının Gelişimi. Ekonomik Yaklaşım, 10(33): $5-26$.

United Nations and World Tourism Organisation. (2018). New York: International Tourism Highlights, United Nations. 
UNWTO (2019). International Tourism Highlights Reports

UNWTO (2019). International tourism up 4\% in first half of 2019, World Tourism Organization reports.https://www2.unwto.org/press-release/2019-09-09/international-tourism-4-first-half2019-world-tourism-organization-reports

Zehrer, A., and Hallmann, K. (2015). A stakeholder perspective on policy indicators of destination competitiveness. Journal of Destination Marketing and Management, 4(2): 120-126.

Zehrer, A., Smeral, E., and Hallmann, K. (2016). Destination Competitiveness Acomparison of Subjective and Objective Indicators for Winter Sports Areas. Journal of Travel Research, 56(1): 5566. 